\title{
Expression of CD56 isoforms in primary and relapsed adult granulosa cell tumors of the ovary Hans-Ullrich Völker*1, Sabine Engert ${ }^{2}$, Andreas Cramer ${ }^{3}$, Melanie Schmidt ${ }^{2}$, Ulrike Kämmerer ${ }^{2}$, Hans-Konrad Müller-Hermelink ${ }^{1}$ and Stefan Gattenlöhner ${ }^{1}$
}

\begin{abstract}
Address: ${ }^{1}$ University of Würzburg, Institute of Pathology, Würzburg, Germany, ${ }^{2}$ University of Würzburg, Dept. of Gynaecology, Würzburg, Germany and ${ }^{3}$ Missionsärztliche Klinik, Dept. of Gynaecology, Würzburg, Germany

Email: Hans-Ullrich Völker* - hans-ullrich.voelker@t-online.de; Sabine Engert - sabine.engert@mail.uni-wuerzburg.de; Andreas Cramer - andreas.cramer@missioklinik.de; Melanie Schmidt - melanie.schmidt@mail.uni-wuerzburg.de; Ulrike Kämmerer - frak057@mail.uni-wuerzburg.de; Hans-Konrad Müller-Hermelink - path062@mail.uni-wuerzburg.de; Stefan Gattenlöhner - stefan.gattenloehner@mail.uni-wuerzburg.de

* Corresponding author
\end{abstract}

Published: 9 July 2008

Diagnostic Pathology 2008, 3:29 doi:10.1 186/1746-1596-3-29
Received: 27 May 2008

Accepted: 9 July 2008

This article is available from: http://www.diagnosticpathology.org/content/3/I/29

(C) 2008 Völker et al; licensee BioMed Central Ltd.

This is an Open Access article distributed under the terms of the Creative Commons Attribution License (http://creativecommons.org/licenses/by/2.0), which permits unrestricted use, distribution, and reproduction in any medium, provided the original work is properly cited.

\begin{abstract}
Background: Adult granulosa cell tumors of the ovary (GCTs) are sex cord stromal tumors of unpredictable behaviour. Up to now, the prediction of the relapsing/malignant potential remains difficult. CD56 (NCAM) in GCTs was previously described in only two studies. However, the expression of its isoforms was not examined.
\end{abstract}

Methods: 30 GCTs ( 16 primaries, 14 relapses) were investigated immunohistochemically with antibodies against Pan-CD56 (CD56 Pan) and the isoform with I40//80 kDa length (CD56/40//80 kDa). The reaction was assessed with respect to percentage of positive cells and intensity of staining.

Results: In all GCTs, CD56 $6^{\mathrm{Pan}}$ was expressed, but differences were found between primaries and relapses. The percentage of CD56 $\mathrm{Pan}$ positive tumor cells was lower in relapses, whereas CD56 140/ $180 \mathrm{kDa}$ showed a higher staining intensity in the latter.

Conclusion: Expression of CD56 is an additional sensitive and helpful immunohistochemical tool for histopathologists diagnosing a GCT. It does not seem possible to provide a validly individual risk assessement. However, the different expression of CD56 isoforms might indicate important changes in the course to a more malignant behaviour.

\section{Background}

Adult granulosa cell tumors (GCTs) of the ovary common are sex cord stromal tumors of unpredictable clinical behavior. They account for $2-5 \%$ of all ovarian neoplasms [1]. The reported 5-year survival is $75-90 \%$ in FIGO stage I, $55-75 \%$ in stage II, and $22-50 \%$ in stages III/IV [2,3]. An important problem for therapeutic deci- sions apart from surgery is the unpredictable course of disease. Considerable efforts have been undertaken to predict the risk of relapse or metastasizing. Correlations between more malignant behavior and patients' age, menstrual status, incomplete surgery, mitotic count, or proliferative activity have been reported [3-6]. The influence of mutated cell cycle regulatory proteins like p53 or other 
molecular changes remained unclear [7-11]. So far, reliable parameters are not defined.

CD56 is expressed in adult neural, neuroectodermal, and neuroendocrine tissue and different tumors [12] as neuroendocrine tumors, plasmocytomas, or melanomas. Its expression identifies a subgroup of tumors with an unfavorable prognosis e.g. in myeloid leukemia, adenoid cystic carcinoma, squamous cell carcinoma, or renal cell carcinoma [13-16].

CD56 is a membrane-bound cell surface sialoglycoprotein and a member of the immunoglobulin supergene family which induce cell-to-cell interactions during embryonic development, cell migration, and organogenesis [17-19]. Three main isoforms with molecular weights of 120,140 , and $180 \mathrm{kDa}$ are known. These are generated from a single gene by alternative splicing. At least 20 major exons contribute for encoding these different isoforms, and further small exons can give rise additional isoforms [17]. The appearance of the $140 / 180 \mathrm{kDa}$ isoform was found to be associated with a higher degree of malignancy [20].

In GCTs, only two studies are available which report an expression of CD56 [21,22]. An analysis of its isoforms was not performed up to now.

\section{Methods}

\section{Specimen}

30 primary and relapsed GCTs of 19 patients (surgery between 1996 and 2007) were investigated. 16 GCTs were primary tumors, 14 were relapses. Eleven relapses of 4 patients were available for direct comparison with the primary. Three further relapsed GCTs were initially diagnosed and treated loco alieno, unfortunately the specimen of their primaries were not disposable for this study. Medical records of all patients were available. The follow up time ranged from 24 months to 16 years.

\section{Staining}

After surgical resection, the specimen were formalin fixed and paraffin embedded. $2 \mu \mathrm{m}$ sections of the routinely processed paraffin blocks were stained with hematoxylineosin (HE) for histopathological diagnosis. Only cases with typical morphology were included. Proving the diagnosis, all cases were stained with vimentin (Mouse, V9, 1:400, DAKO) and inhibin (Mouse, R1, 1:40, Serotec) and found positive.

Immunohistochemical stainings for CD56 were performed in the usual immunoperoxidase technique (Kit: Advance HRP, DAKO). Following antibodies against were

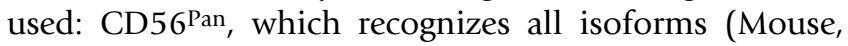
1BC, 1:40, Novocastra), and CD56140/180 kDa (Mouse, NCAM-OB11, 1:500, Sigma). Additionally, Ki67 (MIB-1, 1:200, Dako) was stained. Only areas with antigen integrity (vimentin+, inhibin+) were evaluated. The minimal size of representative areas was $1.5 \times 1.5 \mathrm{~cm}$. One sample per $\mathrm{cm}$ tumor diameter was investigated, the median values were gathered for calculation.

\section{Analysis and Statistics}

Immunohistochemical reactions with CD56 were discriminated in a weak (1), moderate (2), or strong (3) staining intensity. The intensity was assessed by comparison with a strong reaction in the positive controls (small cell neuroendocrine carcinomas of the lung). The percentage of stained tumor cells was determined semiquantitatively.

All data were analyzed using Microsoft Office Excel ${ }^{\circledR}$ and SPSS $^{\circledast}$. The descriptive statistical values, i.e. average, median, minimum, maximum, and standard deviation/ standard error were computed. Furthermore, the significance of differences was tested by Chi-Square test resp. Mann-Whitney-U-test.

\section{Results \\ Clinical data}

Table 1 shows data of patients. 11 patients were premenopausal, 8 postmenopausal at time of first surgery. 12/19

Table I: Clinical data at the time of first surgery

\begin{tabular}{ccc}
\hline & Primaries with relapse & $\begin{array}{c}\text { Primaries without relapse } \\
\text { during observation period }\end{array}$ \\
\hline $\begin{array}{c}\text { Age [years] } \\
\text { (Average, Min, Max) } \\
\text { Menopausal at first } \\
\text { surgery }\end{array}$ & $55.1(23-78)$ & $57.3(34-85)$ \\
Tumor size [cm] & 4 premenopausal & 7 premenopausal \\
(Average, Min, Max) & 3 postmenopausal & 5 postmenopausal \\
FIGO stage & $13.4(2.5-26)$ & $7.8(4-25)$ \\
& $5 *$ FIGO I & $8^{*}$ FIGO I \\
\hline
\end{tabular}


(63.2\%) primaries were free of relapses over 36 months up to 16 years. Relapses occurred 30 months up to 8 years after initial diagnosis, no more than four relapses/patient were found.

In the cases (primaries or relapses) investigated here, the primary tumor stage was in 11 cases FIGO I (IA:7, IB:1, IC:1) and in 6 cases FIGO II (IIA:4, IIB:2). In 2 cases, the FIGO stage was not exactly documented, but the clinical data correspond with FIGO I.

Between primary and relapsed GCTs, patients' age, first tumor stage (mostly FIGO I), or size of primary did not differ significantly.

\section{Conventional parameters}

The proliferation (Ki67) was 4.5\% (1-10) in primaries and $11.3 \%(2-40)$ in relapses $(\mathrm{P}<0.05)$. Moreover, the relapses harbored a significant higher number of cases with a proliferation above $10 \%$ (3/16 vs. 6/12; $\mathrm{P}<$ $0.0001)$. However, the proliferation was not different between primaries with and without relapse $(4.0 \%, 1-5$ vs. $4.6 \%, 1-10)$. The mitotic index per high power field (HPF) did not differ significantly between primaries and relapses (2.0/HPF, $0-10$ vs. 3.3/HPF, $0-17)$ resp. between the two groups of primaries (1.75/HPF, $1-3$ vs. $2.0 / \mathrm{HPF}$, 0-10).

\section{Expression of CD56}

All tumors, both primaries and relapses, stained positive for CD56 ${ }^{\text {Pan }}$. 9/16 primaries $(56.3 \%)$ reacted with CD56140/180 kDa, 8/14 relapses (57.1\%) were positive. In primaries, the median of positive cells for CD56 Pan was 80\% (5-100) and 5\% (5-80) for CD56140/180 kDa $(\mathrm{P}<$ $0.05)$. Relapses showed a median of 35\% (5-100) positive cells in CD56 Pan and 5\% (0-80) for CD56140/180 kDa (P $<0.05)$. Figure 1 gives examples for staining, figure 2 indicates these data in comparison of primaries without

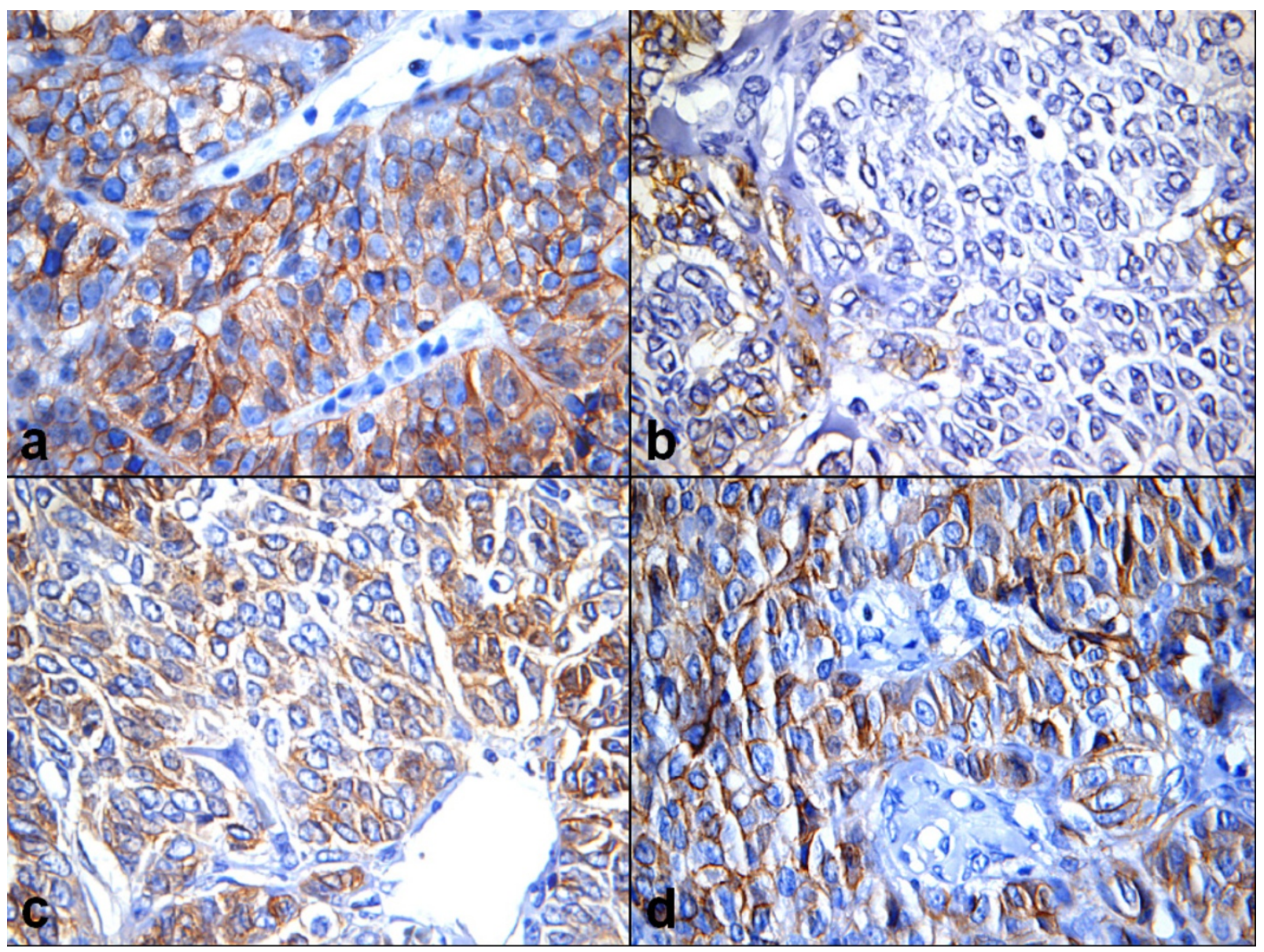

Figure I

Examples for CD56 staining (Immunoperoxidase $\times 400$ ). A) Strong expression of CD56 Pan in nearly all tumor cells in a unrelapsed case, B) Weak reaction with the same antibody in only few tumor cells of a relapse (4th relapse of another case), C) Expression of CD56/40/180 kDa in a relapse, and D) Strong expression of the same in nearly all tumor cells of its primary. 


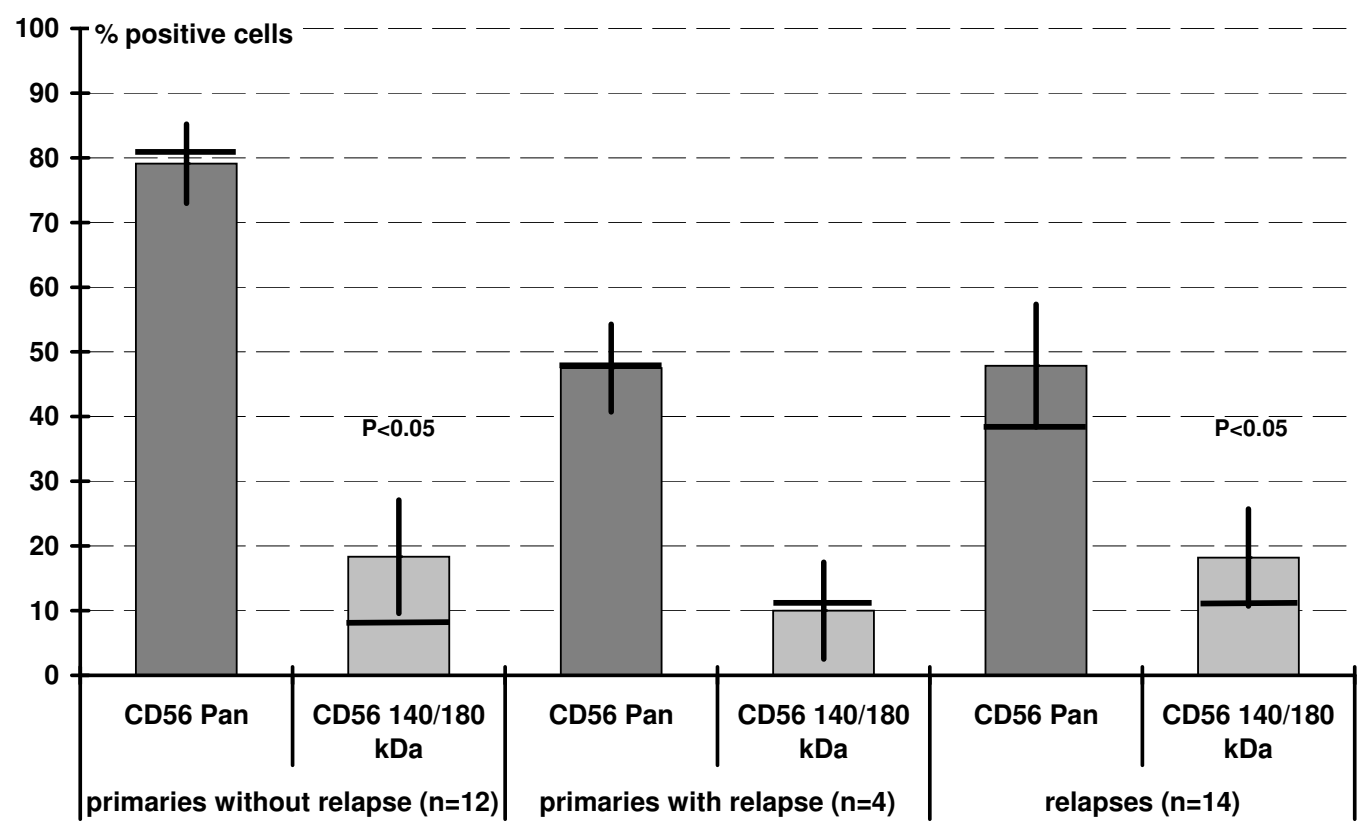

Figure 2

Percentage of positive stained tumor cells (average with standard error, bar: median).

relapse, primaries with relapse and the relapsed tumors. The percentage of positive tumor cell classified in three groups with $>70 \%$, $>50 \%$, and $>30 \%$ positive cells showed no significant differences (figure 3 ).

Positive cells in unrelapsed primaries showed a significant lower staining intensity for CD56140/180 kDa compared with CD56Pan. In relapses and their primaries, the staining intensity was higher than in unrelapsed primaries (figure 4).

CD56 ${ }^{\text {Pan }}$ was strongly expressed in 7/16 primaries and 10/ 14 relapses, CD56140/180 kDa in $1 / 16$ primaries and $4 / 14$ relapses. The differences were not significant.

\section{Discussion}

The expression of CD56 (neural cell adhesion molecule, NCAM) in adult granulosa cell tumor of the ovary (GCTs) was previously described in two studies [21,22]. The expression of $\mathrm{CD} 56^{\text {Pan }}$ and the isoform CD56 140/180 kDa was not investigated up to now.

We investigated 16 primaries and 14 relapses (of together 7 primaries). The number is not high enough for comprehensive statistical evaluation, but seems adequately for insights in expression profiles for CD56 in these rare tumors.
GCTs express CD56 constantly. This finding constitutes a further diagnostic tool for the surgical pathologist apart from inhibin or vimentin. In difficult cases, the differential diagnosis of GCT may be provided by positivity of CD56 in discrimination e.g. of poorly differentiated carcinoma or endometrial stromal sarcoma [21]. However, expression of CD56 alone can not prove a GCT because of the possibility of positive reaction in a lot of other malignant tumors [12-16].

Human granulosa cells of pre-ovulatory follicles and thecal cells have been detected to express CD56 [17,22]. Similar to inhibin or activin, CD56 is a regulator of growth and differentiation in ovarian folliculogenesis [23]. Thus, it is understandable that GCTs express CD56. It seems to be an important factor involved in the recognition and intercellular interaction of ovarian endocrine cells and participates in the regulation of the cyclic remodeling processes of the ovarian endocrine compartments [18].

The major function of CD56 is the homophilic binding NCAM-NCAM [16]. In clusters of granulosa cells of follicles, CD56 was found by Mayerhofer et al., whereas cells devoiding CD56 spread out and form monolayers [18]. CD56 is thought to favor the development of metastases by supporting cell dissociation processes [16,24,25]. We found a less number of tumor cells positive for CD56 Pan 


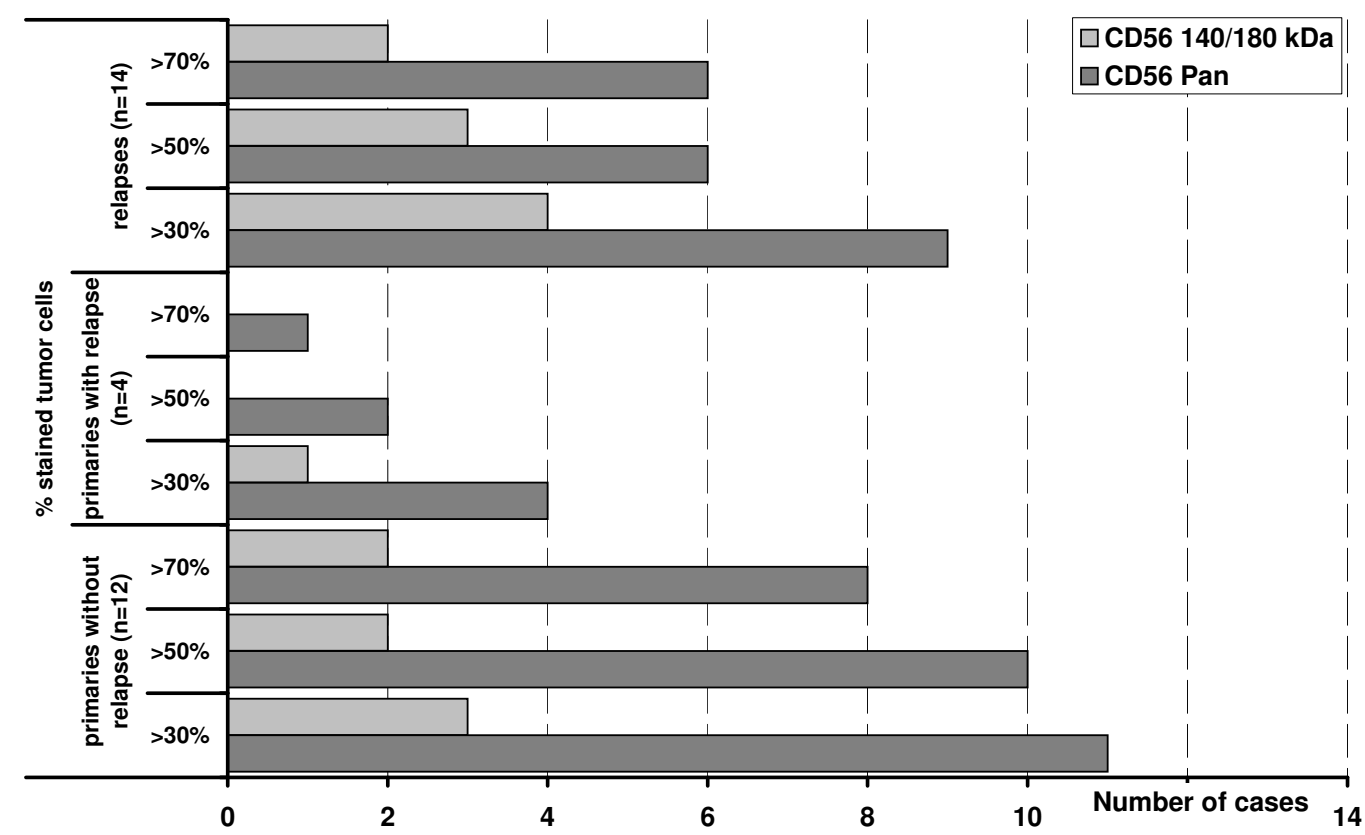

Figure 3

Number of cases distributed in three groups $(>70 \%,>50 \%,>30 \%$ positive cells). No significant differences between primaries with and without relapse and relapses.

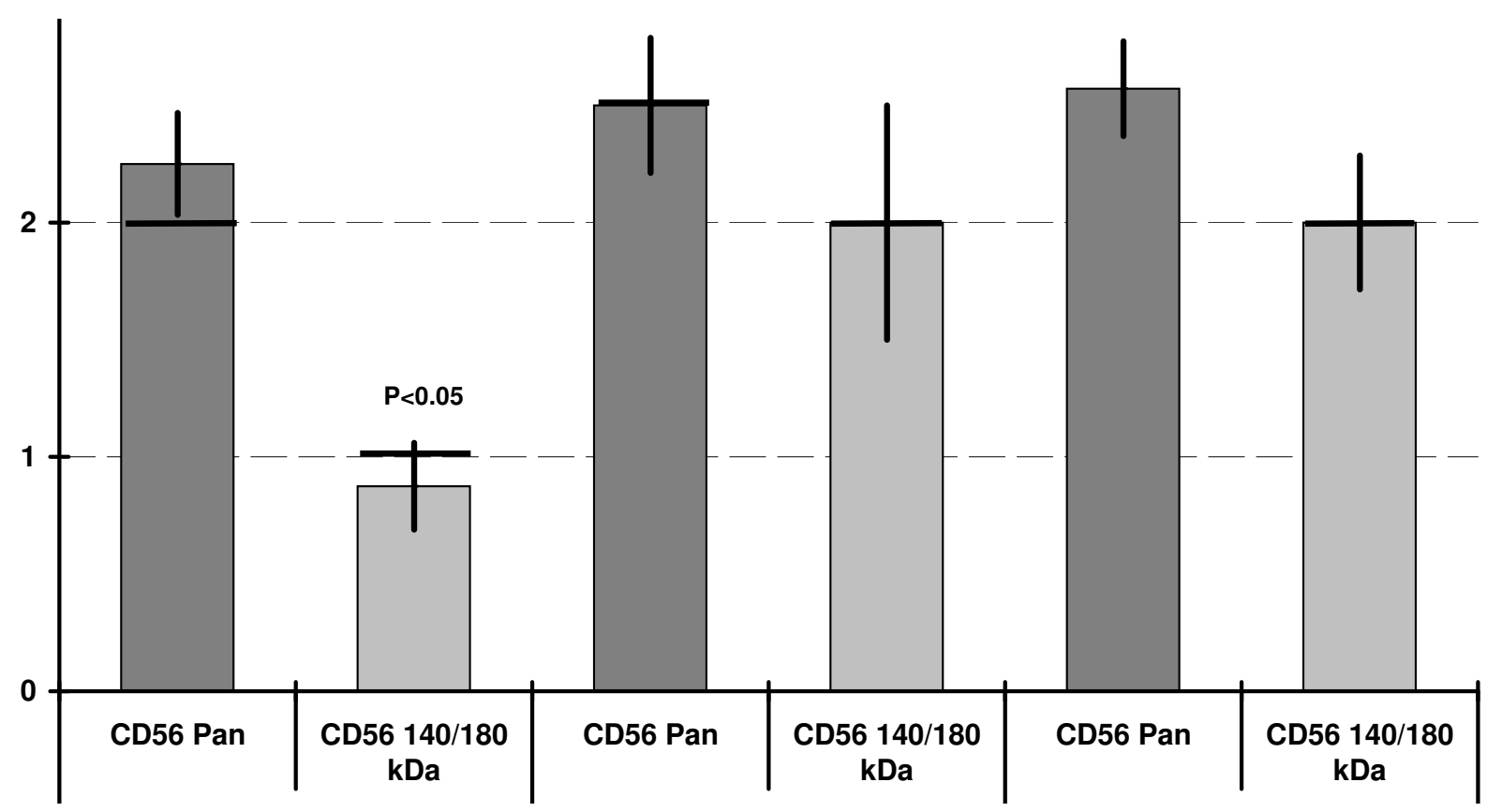

Figure 4

Staining intensity (I-weak, 2-moderate, 3-strong) in the different groups of granulosa cell tumors (average with standard error, bar: median). No significant differences, but trend to a higher staining intensity in primaries with relapse and relapses. Significant lower staining of $\mathrm{CD} 56^{140 / 180 \mathrm{kDa}}$ in primaries without relapse (see also figure 2). 
in primaries with relapse and relapsed GCTs (not significant, but clear trend). Loss of CD56 could be interpreted as a sign of dedifferentiation during the tumor progression and with respect to the binding function of CD56 to a loosening of cell adhesion. Differences in the percentage of positive tumor cells in GCTs were also reported by Ohishi et al., but not analyzed in this matter [21].

In several malignant tumors, CD56 expression predicts a more aggressive biological behavior [13,14,16,24,26,27], especially in presence of the $140 / 180 \mathrm{kDa}$ isoform [20]. In GCTs, we found a more frequent appearance of strong expression of CD56140/180 kDa in relapsing primaries and relapses in comparison to unrelapsed primaries. This shift to the high molecular isoform could be interpreted as a hint for the more aggressive biological behavior of relapsing cases. However, the findings of expression in this small cohort seem sufficient for refusing a predictive value of CD56 expression, because of the heterogenous distribution.

Increased mitotic count and proliferation were associated with relapsing as reported before $[2,28,29]$. However, these markers are also not suitable for prediction of behaviour, because we found only differences between primaries and relapses, but not between relapsing and unrelapsed primaries. Another conventional factors reported associated with a good prognosis are low FIGO stage, small tumor size $(<10-15 \mathrm{~cm})$, and unruptured tumor during surgery [2]. However, even though FIGO stage is thought as an important criterion, the tumor stage does not give valid information regarding the prognosis, since the majority of GCTs is diagnosed at stage I [2].

\section{Conclusion}

CD56 is constantly expressed in adult granulosa cell tumors of ovary. Its expression is most probably determined by tumor histogenesis. Therefore, apart from other immunohistochemical markers like inhibin, the detection of CD56 in GCTs is a helpful diagnostic tool for the histopathologist in difficult cases. However, an individual prediction of clinical behavior via expression of CD56 isoforms is not possible.

\section{Competing interests}

The authors declare that they have no competing interests.

\section{Authors' contributions}

HUV, HKMH, SG Preparation of cases, immunohistochemical investigation, analysis of data, SE, AC, MS analysis of cases, all clinical parts, discussion, UK statistical analysis.

\section{Acknowledgements}

We thank Petra Stempfle and Margit Bonengel for immunohistochemical investigation, especially for establishment of CD56/40//80 kDa. Thank also to Erwin Schmitt for processing the figures.

\section{References}

I. Ala-Fossi SL, Aine R, Punnonen R, Maenpaa J: Is potential to produce inhibins related to prognosis in ovarian granulosa cell tumors? Eur J Gynaecol Oncol 2000, 21:187-189.

2. Schumer ST, Cannistra SA: Granulosa cell tumor of the ovary. J Clin Oncol 2003, 21: I I80-1 I89.

3. Stuart GC, Dawson LM: Update on granulosa cell tumours of the ovary. Curr Opin Obstet Gynecol 2003, 15:33-37.

4. Mehta H, Trivedi P, Parikh B, Shukla K, Shah MJ: Clinicopathological prognostic factors of adult granulosa cell tumor of the ovary--a study of $\mathbf{3 7}$ cases. Indian J Pathol Microbiol 2005, 48:439-443.

5. Sehouli J, Drescher FS, Mustea A, Elling D, Friedmann W, Kuhn W, Nehmzow M, Opri F, Klare P, Dietel M, Lichtenegger W: Granulosa cell tumor of the ovary: 10 years follow-up data of 65 patients. Anticancer Res 2004, 24: 1223-1229.

6. Staibano S, Franco R, Mezza E, Chieffi P, Sinisi A, Pasquali D, Errico ME, Nappi C, Tremolaterra F, Somma P, Mansueto G, De Rosa G: Loss of oestrogen receptor beta, high PCNA and p53 expression and aneuploidy as markers of worse prognosis in ovarian granulosa cell tumours. Histopathology 2003, 43:254-262.

7. Kusamura S, Derchain S, Alvarenga M, Gomes CP, Syrjanen KJ, Andrade LA: Expression of p53, c-erbB-2, Ki-67, and CD34 in granulosa cell tumor of the ovary. Int J Gynecol Cancer 2003, 13:450-457.

8. Gebhart JB, Roche PC, Keeney GL, Lesnick TG, Podratz KC: Assessment of inhibin and $\mathrm{p} 53$ in granulosa cell tumors of the ovary. Gynecol Oncol 2000, 77:232-236.

9. Ala-Fossi SL, Maenpaa J, Aine R, Koivisto P, Koivisto AM, Punnonen $R$ : Prognostic significance of p53 expression in ovarian granulosa cell tumors. Gynecol Oncol 1997, 66:475-479.

10. Liu FS, Ho ES, Lai CR, Chen JT, Shih RT, Yang CH, Tsao CM: Overexpression of $\mathrm{p} 53$ is not a feature of ovarian granulosa cell tumors. Gynecol Oncol 1996, 61:50-53.

II. Costa MJ, Walls J, Ames P, Roth LM: Transformation in recurrent ovarian granulosa cell tumors: Ki67 (MIB-I) and p53 immunohistochemistry demonstrates a possible molecular basis for the poor histopathologic prediction of clinical behavior. Hum Pathol 1996, 27:274-28I.

12. Lantuejoul S, Laverriere MH, Sturm N, Moro D, Frey G, Brambilla C, Brambilla E: NCAM (neural cell adhesion molecules) expression in malignant mesotheliomas. Hum Pathol 2000, 31 :4 I 5-42 I.

13. Raspadori D, Damiani D, Lenoci M, Rondelli D, Testoni N, Nardi G, Sestigiani C, Mariotti C, Birtolo S, Tozzi M, Lauria F: CD56 antigenic expression in acute myeloid leukemia identifies patients with poor clinical prognosis. Leukemia 200I, 15:II6I-I|64.

14. Gandour-Edwards R, Kapadia SB, Barnes L, Donald PJ, Janecka IP: Neural cell adhesion molecule in adenoid cystic carcinoma invading the skull base. Otolaryngol Head Neck Surg 1997, I 1 7:453-458.

15. Vural E, Hutcheson J, Korourian S, Kechelava S, Hanna E: Correlation of neural cell adhesion molecules with perineural spread of squamous cell carcinoma of the head and neck. Otolaryngol Head Neck Surg 2000, I 22:717-720.

16. Daniel L, Bouvier C, Chetaille B, Gouvernet J, Luccioni A, Rossi D, Lechevallier E, Muracciole X, Coulange C, Figarella-Branger D: Neural cell adhesion molecule expression in renal cell carcinomas: relation to metastatic behavior. Hum Pathol 2003, 34:528-532.

17. Mayerhofer A, Lahr G, Frohlich U, Zienecker R, Sterzik K, Gratzl M: Expression and alternative splicing of the neural cell adhesion molecule NCAM in human granulosa cells during luteinization. FEBS Lett 1994, 346:207-212.

18. Mayerhofer A, Lahr G, Gratzl M: Expression of the neural cell adhesion molecule in endocrine cells of the ovary. Endocrinology 1991, I 29:792-800.

19. Mayerhofer A, Seidl K, Lahr G, Bitter-Suermann D, Christoph A, Barthels $D$, Wille W, Gratzl M: Leydig cells express neural cell adhesion molecules in vivo and in vitro. Biol Reprod 1992, 47:656-664. 
20. Perl AK, Dahl U, Wilgenbus P, Cremer H, Semb H, Christofori G: Reduced expression of neural cell adhesion molecule induces metastatic dissemination of pancreatic beta tumor cells. Nat Med 1999, 5:286-29|.

21. Ohishi Y, Kaku T, Oya M, Kobayashi H, Wake N, Tsuneyoshi M: CD56 expression in ovarian granulosa cell tumors, and its diagnostic utility and pitfalls. Gynecol Oncol 2007, 107:30-38.

22. McCluggage WG, McKenna M, McBride HA: CD56 Is a sensitive and diagnostically useful immunohistochemical marker of ovarian sex cord-stromal tumors. Int J Gynecol Pathol 2007, 26:322-327.

23. Findlay JK, Drummond AE, Dyson M, Baillie AJ, Robertson DM, Ethier JF: Production and actions of inhibin and activin during folliculogenesis in the rat. Mol Cell Endocrinol 200I, 180:139-I44.

24. Mooy CM, Luyten GP, de Jong PT, Jensen OA, Luider TM, van der Ham F, Bosman FT: Neural cell adhesion molecule distribution in primary and metastatic uveal melanoma. Hum Pathol I995, 26: II85- II90.

25. Crnic I, Strittmatter K, Cavallaro U, Kopfstein L, Jussila L, Alitalo K, Christofori G: Loss of neural cell adhesion molecule induces tumor metastasis by up-regulating lymphangiogenesis. Cancer Res 2004, 64:8630-8638.

26. Chang H, Samiee S, Yi OL: Prognostic relevance of CD56 expression in multiple myeloma: a study including 107 cases treated with high-dose melphalan-based chemotherapy and autologous stem cell transplant. Leuk Lymphoma 2006, 47:43-47.

27. Fogar P, Basso D, Pasquali C, De Paoli M, Sperti C, Roveroni G, Pedrazzoli S, Plebani M: Neural cell adhesion molecule (NCAM) in gastrointestinal neoplasias. Anticancer Res 1997, 17:1227-1230.

28. King LA, Okagaki T, Gallup DG, Twiggs LB, Messing MJ, Carson LF Mitotic count, nuclear atypia, and immunohistochemical determination of $\mathrm{Ki}-67$, c-myc, p2I-ras, c-erbB2, and p53 expression in granulosa cell tumors of the ovary: mitotic count and Ki-67 are indicators of poor prognosis. Gynecol Oncol 1996, 61:227-232.

29. Fujimoto T, Sakuragi N, Okuyama K, Fujino T, Yamashita K, Yamashiro S, Shimizu M, Fujimoto S: Histopathological prognostic factors of adult granulosa cell tumors of the ovary. Acta Obstet Gynecol Scand 200I, 80: 1069-1074.

Publish with Biomed Central and every scientist can read your work free of charge

"BioMed Central will be the most significant development for disseminating the results of biomedical research in our lifetime. "

Sir Paul Nurse, Cancer Research UK

Your research papers will be:

- available free of charge to the entire biomedical community

- peer reviewed and published immediately upon acceptance

- cited in PubMed and archived on PubMed Central

- yours - you keep the copyright

Submit your manuscript here:

http://www.biomedcentral.com/info/publishing_adv.asp
BioMedcentral 